\title{
Discourse Analysis of Tennessee Williams' The Glass Menagerie
}

\author{
George Mathew Nalliveettil (Corresponding author) \\ Department of English, Aljouf University, P.O. Box 2014, Sakaka, Al-Jouf, Saudi Arabia \\ E-mail: ngeorgeresearch@gmail.com \\ Mahmoud Sobhi Mohamed Gadallah \\ Department of English, Aljouf University, P.O. Box 2014, Sakaka, Al-Jouf, Saudi Arabia \\ E-mail: gadallah2013@gmail.com
}

Doi:10.7575/aiac.alls.v.7n.3p.201

URL: http://dx.doi.org/10.7575/aiac.alls.v.7n.3p.201
Received: 24/01/2016

Accepted: 30/03/2016

This research project is funded by Deanship of Scientific Research, Aljouf University, Saudi Arabia. It carries the number (35/319).

\begin{abstract}
The Glass Menagerie is one of the Tennessee Williams' most famous plays which won the New York Drama Critics' Circle award. It elevated him to be one of the greatest playwrights of his generation. As a playwright, he is skilful to make the readers conscious of the unconscious habits and attitudes in everyday life. In The Glass Menagerie, Tennessee Williams (1911-1983) portrayed family relationships and struggles against hopelessness that threatens their lives. The present study made a discourse analysis of Tennessee Williams' The Glass Menagerie. This discourse analysis of the dialogic language was based on dialogic principles outlined by Weigand (2009). The researchers applied these principles to uncover conventional and unconventional elements embedded in the structures of the language. The study also analyzed the discourse contexts and their impact on the meaning of the given different situations that the main characters, i.e., Amanda, Laura, Tom Wingfield, encounter during the ongoing actions of the play. This research, furthermore, presented insights on how Tennessee Williams achieved the intended dramatic effect in the discourse of the characters. The introductory part of the research paper presented the features of a dramatic discourse in relation to language of The Glass Menagerie. A review of literature related to the play gives a summary of the literary and linguistic research carried out by different researchers to understand the play from various aspects. A detailed linguistic analysis unravels the functional aspects of dialogic discourse that are embedded in the lines of the text. The findings unfold the logics concealed in the dialogues and kind of structures used for dramatic effect.

Keywords: discourse, dialogic, dramatic, analysis, principles, characters

1. Introduction

Verbal and non-verbal communications, which are considered to be vital tools for human existence, have been a source and a medium of theatrical performance from the ancient to the postmodern periods of English drama. The dramatists from the ancient era to the post-modern period have been synchronizing the usage of literary and linguistic devices to meet the feelings, needs, wishes, dreams, emotions and interests of the readers and the audiences. During the postmodern period of American literature, The Glass Menagerie is considered to be Tennessee Williams' first successful play. Williams became famous due to the effective theatrical scenes he composed in The Glass Menagerie. His artistic skill to intermix comic and tragic elements, using wide varieties of symbolism in the play, draws the attention of literary critics and linguists to explore meaning behind clauses and phrases intertwined in each of the dialogue. Play-texts, however, when compared with poems and fictional prose, received little attention from twentieth-century literary critics as well as from linguistic analysts (Verdonk et al., 2013). Therefore, the main purpose of this research is to analyze the discourse of the play linguistically in order to derive the meaning and the significance of the complex structures that the playwright intentionally hides in the text of the play.

1.1 Dramatic Discourse

In a dramatic discourse, a playwright uses a variety of literary genres and syntactic structures to communicate personal emotions and societal norms. However, in formal and informal conversations, people often communicate their ideas and emotions in a language that can be understood to each other. When the same ideas and emotions are scripted in a play, the playwright not only tends to elevate the language and make it appear more dramatic but also exploits or manipulates the principles, norms and conventions that are used to construct dialogues, speech types and forms in plays (Herman, 1995). A dramatic discourse becomes meaningful when readers authenticate it to their personal, family and social life. In a dramatic discourse, the fictional figures are often depicted as either complying or disobeying the values and norms of a family or society. A playwright, furthermore, vocalizes these actions and interactions of common men and women using diction and figurative language. Thus, a dialogue becomes more effective and superior to that of an ordinary
\end{abstract}


speech when a combination of literary and linguistic devices is integrated into it. These ideas coincide with Herman's (1995) remarks as she states that the bulk of this dialogic discourse which is carried over by specific participants, in spatio-temporal settings of one kind or another, and interactions among the characters, unfolds the relevant situations of the plot. In order to make these interactions between the major and minor characters lively, a playwright reproduces the style or genre of spoken discourse to create a dramatic effect in the minds of readers (Pavis, 1998).

In The Glass Menagerie, Tennessee Williams dramatizes the discourse among the characters through dramatic conflicts, and witty words to make it acceptable to the intellect and emotions of the readers. The language of the dialogic-conversation among the characters shapes their identities and unravels their approach to different circumstances and situations.

\subsection{Reflections on the Language of Expressionism in The Glass Menagerie}

A common criticism leveled against the playwrights' belonging to realism and naturalism is their focus on surface reality. However, the expressionists portrayed the deeper reality that lies beneath and beyond the surface discourse of the characters (Syed). The term 'memory play', coined by Tennessee Williams and presented in the "Production Notes" of The Glass Menagerie, reflects the psychological representation of the playwright's identity through his characters. For Williams, the theater is a place of imagination that is beyond the poetry of words, where the poetry of gesture, design, lighting, acting come together and meet above and between the actors (Lunden, 2013a). Williams' position as a writer and a painter is visible in his intense interest in the pictorial arts, coupled with the way images intertwines themselves into the themes of his text, (Maruejouls-Koch 2012). Even Cherry Jones, an American actress who played the role of Amanda, observed that she wished people who hate the theater to see The Glass Menagerie because it takes people to places they have never been before and will change people's minds about the theater (Lunden, 2013b).

1.3 Tennessee Williams' Approach in The Glass Menagerie

In 'Production Notes', Tennessee Williams observes that "The Glass Menagerie can be presented with unusual freedom of convention" (p. 1) signaling the impact of expressionism in Williams' plays and distancing from the literary movements of realism and naturalism. The Glass Menagerie is considered to be an expressionistic play because of the integration of rational, emotional, psychological, visual and cognitive domains. The conflict between rationality and emotions often set the tone of discourse among the characters, i.e., Amanda, Laura, Tom and Jim. Furthermore, Tennessee Williams believes that truth, life, and reality are intrinsic aspects of human nature. In the 'Production Notes', he remarks that an exposition of these intrinsic aspects requires a poetic imagination. Therefore, he expects the readers to understand the dialogues using higher order cognitive skills. The current research examines the implied meanings and outcomes of different situations using the dialogic principles outlined by Weigand (2009). The study, furthermore, expounds the deep meanings that lie beneath and beyond the surface dialogues of The Glass Menagerie.

\section{Researching The Glass Menagerie: Applying Linguistic Principles}

The playwrights of the post-modern era have distanced themselves from the conventional forms of using literary genres and moved closer to more unconventional writing techniques whereby the phrases and sentences embedded in the dialogues have linguistic significance. However, most of the research done on The Glass Menagerie was confined to the analysis of literary genres, themes, and symbolism. Many studies in The Glass Menagerie focused on literary and stylistic elements while the key aspects of language use to express rationality, emotions and psychological states of characters remain to be explored. In an early study on The Glass Menagerie done by King (1973), aspects like characterization, the nature of narration, the autographical elements, and irony in soliloquies were analyzed. His focus is to illustrate the meaning and relevance of the various soliloquies in the play. In her article titled 'Exceptionality Versus Normativity in The Glass Menagerie', Hoffmannová draws similarities between Tennessee Williams' plays and Foucault's social theory. She approaches The Glass Menagerie with a precondition that the characters belong to outcasts. Her primary focus was on the character of Laura and Tom. She points out that, on one hand, Laura finds it difficult to lead an independent life of her own within the community, and on the other hand, Tom suffers from mental and emotional pain due to his family circumstances. In another study, Gräfe (2007), considered the social and economic situation in America during the period when The Glass Menagerie was written. Gräfe approached the social aspect of the play, with a special emphasis on the image of Amanda. Fernkorn (1999) focused her research on analyzing the relationship between each one of the characters in the play to the other. In his research paper, Friedrich (2010) discussed the topic of 'soft people' in Tennessee Williams' The Glass Menagerie and A Streetcar Named Desire. According to Friedrich, a key to understand Williams' work is to explore how he related the themes and motifs, apparent in his plays, to his personal life. In his study, Chowdhury (2014) analyzes the dream, desire, and memory depicted in The Glass Menagerie and manifests them to the social and economic conditions of the middle-class people in the American society. In his research, Barnard (2007) selected dialogues, characterization, plot, and setting in The Glass Menagerie based on their potential to represent Williams' identity and experience to show the conflict between spirit and flesh. Barnard is of the opinion that the character of Laura is a symbolic representation of spirit while her brother, Tom, represents flesh. Tabasum (2013) applied a deconstructive theoretical approach on the plays of Tennessee Williams to explore the idea of optimism. With reference to The Glass Menagerie, he argues that the whole plot of The Glass Menagerie focuses on Tom Wingfield's past memories. The linear incidents of the play, furthermore, show that Tom followed his father's steps of ignoring the family responsibilities. Tabasum stated that the method of presenting the incidents in the play is that of storytelling.

Islamiah (2012) used a pragmatic approach to analyze and interpret the dialogues of The Glass Menagerie. Her study primarily focuses on the dialogues among the characters to find out the violations of the maxims of cooperative principle. She interpreted how each of the characters violated the principles of cooperative maxims based on the context and the way the characters interacted in the play. A Maxim, according to Islamiah, is "a rule that people must fulfill in a 
good conversation, but in communication, the speaker utterances usually do not always follow the rules. There might be flouting of cooperative principle" (p. 14). Her findings suggest that the characters have violated maxim of quantity, quality, relevance and manner while the character Laura is considered to be violating the cooperative principle more dominantly when compared to the other characters in The Glass Menagerie. However, Hama (2016) draws attention to the conversation between Amanda, Tom and Laura to highlight how personal and cognitive contexts help to understand the meanings of their utterances. According to him, the conversation between Amanda and Tom is a reminder of the maxims of manner because the characters are habituated to frequent interruptions and their reactions are a result of implied meanings rather than surface meaning. With an exception of Islamiah's pragmatic study on violations of cooperative principles and Hama's study on personal and cognitive contexts, all of the studies mentioned above approached The Glass Menagerie from literary points of views. However, an important characteristic that makes this study different from previous ones is that it interprets the play from dialogic principles outlined by Weigand (2009). According to her, the process of comprehending meaning of an utterance requires an understanding of its function in the context of dialogic interaction among the characters.

Rationality and emotions, furthermore, are constitutive parts of human behavior (Daneš, 1997), and are also general themes in The Glass Menagerie wherein the characters act and react via dialogic interactions. Weigand (2009), however, is of the opinion that the orthodox speech act theories that were used to analyze plays have ignored the concepts of the functional language that influence dialogic action game. In order to understand the feelings such as love, hatred, jealousy, anger, joy, sadness, disappointment, irritability, sensibility, aggression, and stress that a playwright depicts through his characters, Weigand recommends to study systematically the functional language that influences dialogic action game. Furthermore, Tennessee Williams' skill to integrate rationality, displeasure, unhappiness, failures, anger, anxiety, confusion, frustrations and happiness in the dialogic language of his characters necessitates an intensive linguistic study. Therefore, the current research explores the functional aspects of the dialogic language in The Glass Menagerie.

\section{Research Questions}

This study is intended to examine the following research questions:

- Whether the dialogic language scripted in The Glass Menagerie follows conventional or unconventional techniques of language use.

- To what extent does a playwright adhere to the linguistic principles that make a dialogic written language fulfill the function of spoken discourse?

- How to understand the play from the context of the mutual relationship between the dialogic purposes and communicative means?

- How to approach the play from the perspective of dialogic language?

\subsection{Description of the Data}

The source of data for our research is the discourse of The Glass Menagerie, a 20th-century American drama. The text has seven scenes, with four major characters namely; Amanda, Tom, Laura and Jim, while the character Tom has two roles in the play, i.e., as a narrator and as an actor. For the purpose of analysis, exact citations with their page numbers are taken from Tennessee Williams' The Glass Menagerie, edited by Leslie McPherson (2002). The playwright highlights important themes through the dialogic action among these characters. For the purpose of analysis, the researchers selected certain dialogues. These dialogues are chosen from different scenes. The data analysis of the dialogic discourse in The Glass Menagerie is based on the principles outlined by Weigand. She points out that the dialogic action game is based on a two-part sequence of action and reaction with human beings at the centre of this discourse.

\section{Data Analysis}

The discourse in The Glass Menagerie is analyzed by the nine dialogic principles outlined by Weigand (2009). According to her, the following principles characterize the dialogic actions:

1. The Action Principle

2. The Dialogic Principle

3. The Sequencing Principles

4. The Principle of Different Worlds

5. The Open-System Principle

6. The Principle of Suggestion

7. The Rationality Principle

8. The Conventionality Principle

9. The Principles of Emotions

She defines the term 'principle' from the linguistic point of view as "a technique of orientation in complex and open surroundings" (p. 273). Considering the linguistic significance of these nine principles, and also of their importance as interdisciplinary tools to analyze the dialogic language, the researchers applied these principles to analyze the discourse in The Glass Menagerie. The interpretation of data focuses on the dialogic language that integrates verbal, visual and cognitive elements. 
4.1 The Action Principle

The language actions of human beings, according to Weigand (2009), can be understood by relating dialogic purposes and communicative means. She understood the action principle as "the principle of trying to achieve communicative purposes by communicative means" (p. 182). Weigand is also of the opinion that one cannot separate verbal ability from other cognitive skills. Weigand also points out that thinking involves self-communication and an individual often communicates with a purpose in mind. As a habit, an individual simultaneously uses his/her ability to speak, see and think while communicating with others. At the same time, a playwright has to skillfully transform the spoken discourse into a written form because the scripted language should make the readers see, understand and think of the situation.

\section{Datum 1, Scene One}

Tom: Yes, I have tricks in my pocket, I have things up my sleeve. But I am the opposite of stage magician. He gives you illusion that has appearance of truth. I give you truth in the pleasant disguise of illusion. To begin with, I turn back time. (Pp. 6-7)

The action of the play begins with a dialogic purpose using the first person singular; "Yes, I have", aiming to open rapport with the readers who might be eager to know what the 'tricks in my pocket' mean. This introductory address to the readers scripted in direct speech fulfills the dialogic purpose of establishing a direct contact with the readers and briefing them about the historical relevance of the play. In order to serve the purpose of informality and make it appear as an 'exact address' to the readers, the playwright intentionally disregards punctuation rules. Earlier in the text, readers are informed that "Tom enters dressed as a merchant sailor" and before addressing the audience "he stops and lights a cigarette." These actions of Tom are rather confusing because it is quite unconventional for an addressee to dress differently and smoke while addressing a gathering. However, it seems that there is a purpose for his action of dressing like a merchant sailor and to light a cigarette because the speaker has two roles in the play, i.e. the stage director and also as a character.

These actions conveyed via language are hints of the speaker's role as a younger Tom, who is habituated to smoking and always dreams of new adventures in life. Also, the self-revelation of the role of the speaker through different language cues: 'opposite of stage magician' and 'I turn back time', indicates his role as a stage director. Thus, the appearance, actions and the tone of the verbal address of the speaker, Tom, in the opening lines of Scene One are intended to fulfill the communicative purpose of creating a dramatic effect in readers' minds. Therefore, readers have to use their cognitive skills to understand the message of the written discourse.

4.1.1 Small Talk

A small talk is an initiation by a character which might not just represent his/her mood but also by a sense of obligation to talk to another character (Weigand, 2009). A communicative purpose of a small talk serves the need to establish or confirm social relationships. Thus, for every action and utterance, there is some dialogic intention.

Datum 2, Scene One

Amanda [calling]: Tom?

Tom: Yes, Mother.

Amanda: We can't say grace until you come to the table!

Tom: Coming, Mother. (P. 8)

The little initial interaction among the characters might arise from the need of one or more persons to communicate or to get closer to each other. Tennessee Williams introduces the characters of Amanda and Tom to the play, highlighting the kinship between them. As it is apparent from the citation, Amanda initiates the conversation to establish and continue the social obligation of a mother reminding her son to follow the social norms of dining together with other members of a family. Tom, respecting the utterance of his mother, responds to her and obliges to be present for the meal. This initial dialogue between Amanda and Tom gradually progresses towards a chain of conversations which add to the edifice of the play.

In order to end a conversation, one has to presuppose many things, and sometimes these presuppositions cannot be expressed explicitly. There is a possibility of mutual understanding and also a risk of misunderstanding an utterance because individuals make moment-by-moment judgments as well as draw various types of rational and conventional conclusions (Weigand, 2009). Amanda's presupposition that gentleman callers are expected to visit their house at any time reminds her to caution Laura to stay pleasant and good-looking to welcome these young men. However, Laura's rational presupposition of her current circumstances makes her give a reactive statement that she is not expecting any gentleman callers.

Datum 3, Scene One

Laura [sitting down]: I'm not expecting any gentleman callers.

Amanda: [crossing out to kitchenette, airily]: Sometimes they come when they are least expected! Why, I remember one Sunday afternoon in Blue Mountain - [She enters the kitchenette.]

Tom: I know what's coming!

Laura: Yes. But let her tell it.

Tom: Again?

Laura: She loves to tell it. (P. 9) 
The playwright slowly shifts the topic of discussion towards the past life of Amanda, making her recall the past events related to her pre-marital experience. The utterance "Why, I remember one Sunday afternoon in Blue Mountain" by Amanda makes Tom and Laura to make contextual presuppositions. The word 'remember' in Amanda's statement triggers the other characters to predict what she is expected to speak on. However, the readers/audience might rely on the presuppositions of the characters to understand the reference to which Amanda makes. The moment-by-moment judgments based on the presuppositions make others' speech acceptable or unacceptable. These presuppositional exchanges of Tom and Laura remain as a small talk between them but are not stated explicitly to Amanda. While Laura sympathizes with the attitude of Amanda, Tom finds it annoying to listen to the narration of his mother.

Based on the dialogue among Laura, Amanda and Tom, readers have to presuppose that Amanda has spoken about the same topic many times in the past. Thus, this discourse accepts two levels of presupposition: one, at the level of the characters and secondly, at the level of the readers. At the level of the characters, Tom and Laura predict what Amanda might say about her past life. Taking hints from the ongoing dialogues among Tom, Laura and Amanda readers can presuppose that this situation occurred many times wherein Amanda mentioned the same topic frequently in the past. This dialogic language intensifies the realistic elements, thus elevating it to a memory play.

4.2 The Dialogic Principle

The dialogic principle is a minimal action game consisting of a two-part sequence, namely: initiative and reactive speech acts. The initiative action makes a pragmatic claim while the reactive move fulfills the claim. Initiative as well as reactive speech acts are communicatively interdependent and find their place in dialogic acts (Weigand, 2009). A Minimal dialogic action game also conveys that both speakers are aware of their respective positions.

\section{Datum 4, Scene One}

Tom: I'm getting a cigarette.

Amanda: You smoke too much. (P.9)

The two speech acts, as we read above, are interdependent. The act of Tom signifies his intention to smoke at that moment while the reactive utterance of Amanda cautions him of excessive smoking. Tom's action of communicating his immediate desire to fetch a cigarette draws a reactive move from Amanda clarifying Tom's smoking habits. Tom's reference to 'cigarette' reminds Amanda of the synonym 'smoke'. The contextual reference to 'smoke' by the interlocutor gives it a particular meaning associated with 'cigarette'. The dialogic inference of the above speech act also informs the readers that Tom is an adult, and it is not for the first time he is smoking. Tom's dialogic language expresses his freedom and intention to smoke while Amanda's reaction symbolizes the concern of a worried mother. The tone of the above speech acts shows the playwright's skillful manipulation of dialogic action, unraveling the relationship between a son and his mother.

\subsection{The Sequencing Principles}

The rules of the dialogic sequence of individual speech acts for linguistic action do not require an establishment of understanding the contextual meaning of an utterance but are derived from an initiative speech act (Weigand, 2009). In the below utterance, an element of exclamatory 'shhh' conveys the message that Laura is cautioning Tom to be silent.

Datum 5, Scene Four

Laura: Tom - shhh! (P.29)

Though Tom understands the meaning of the utterance, the reason is still not clear for Laura's shushing. The following dialogic sequence clarifies Laura's linguistic action.

Tom: What're you shushing me for? (P.29)

The above utterance, which is a reactive question, reveals the problem of incomprehensibility in the mind of the interlocutor. The need for clarification in Tom's reactive move signifies a case of dependence on Laura for precise information. Furthermore, the above dialogic sequence is a reflection of real life situations where individuals rely on a speaker to clarify the the unexpected misunderstanding. In The Glass Menagerie, the playwright's skillfulness in structuring the sequences of dialogic action games gives meaning to the linguistic actions of the characters. Also, the readers' curiosity about the sequence of events within the context of the play is aroused because each independent utterance gives some meaning but not complete sense. Readers have to rely on the reactive moves of the interlocutors to understand the actions of the characters.

4.4 The Principle of Different Worlds

There are communicative situations where the actions of the speakers and the listeners are misunderstood primarily due to variations in the worldly views (Weigand, 2009). When people interact in a particular context, they bring with them different world views and preferences, which may lead to differences in the communicative world of the speaker and the hearer. Reflecting on the discourse of The Glass Menagerie, it is observed that the playwright dealt with the worldly views to shed light on attitudinal variations among the characters.

Datum 6, Scene Three

Tom: - in my life here that I can call my OWN! Everything is -

Amanda: Stop that shouting! 
Tom: Yesterday you confiscated my books! You had the nerve to -

Amanda: I took that horrible novel back to the library - yes! That hideous book

by that insane Mr. Lawrence. [Tom laughs wildly.] I cannot control the

output of diseased minds or people who cater to them - BUT I

WON'T ALLOW SUCH FILTH BROUGHT INTO MY HOUSE! No, no, no, no, no! (Pp.23)

In the above dialogue, Amanda considers Tom's sense of obsession in possessing the books of a particular writer, Mr. Lawrence, as unethical and unacceptable behavior. This action game of misunderstanding can be inferred from the discourse of Tom where the phrase 'my life' and 'can call my OWN' describes the cognitive reaction of understanding and analyzing Amanda's behavior. The sense of ownership that Tom claims over the book, furthermore, is challenged and ridiculed by Amanda's reproach. Even the intensity of negativity in Amanda's language is explicitly stated with the phrase 'that horrible novel' to rebuff the accusations and criticism leveled against her action of 'confiscating' Tom's books. The apparent dispute, in the above citation, also highlights Amanda's assertiveness of reprimanding Tom's choice to read books of a particular author for fulfilling his reading desire. She considers his reading interests as an 'output of diseased minds' and the phrase 'MY HOUSE' signals her authority over the phrase 'my OWN' expressed by Tom.

The speaker, Amanda, seems to have a deep-rooted perception that it is immoral to read the books of Mr. Lawrence. These worldly views about Mr. Lawrence initiate Amanda to revolt against her son's reading habits of such books. On the other hand, Tom's passionate approach towards the books is explicit from his reactions when he realizes the loss of these books from his possession. This particular incident in The Glass Menagerie reaches to an extent of extreme disapproval of each other's interlocution, with Tom passing an unpleasant comment "you ugly - babbling old - witch", and to which Amanda reacts violently signaling her decision that "I won't speak to you - until you apologize!" These interpretations coincide with Weigand's view that states an understanding and accepting each other's viewpoint will always be quite difficult or impossible if both interlocutors interact with a very different cognitive background. She also opines that the differences in worldly views and different ways of communicating with the speakers are indications of the limitations of human rationality.

Furthermore, the playwright depicts the psychological and attitudinal conflicts in the action games through the dialogic principle of different worlds.

4.5 The Open-System Principle

The abrupt introduction of an action game without any reference to the context requires the readers to focus on what the interlocutors are referring to. It is because the playwright introduces certain dialogues which are not coherently linked to any of the earlier actions in the text. Here is a part of a scene that illustrates the open system principle.

\section{Datum 7, Scene Four}

Amanda [calling from the kitchenette]: Laura, are you going to do what I asked you to do, or do I have to get dressed and go out myself?

Laura: Going, going-soon as I get on my coat! [...] Butter and what else?

Amanda [entering from the kitchenette]: Just butter. Tell them to charge it.

Laura: Mother, they make such faces when I do that.

Amanda: Sticks and stones can break our bones, but the expression on $\mathrm{Mr}$.

Garfinkel's face won't harm us! Tell your brother his coffee is getting cold. (Pp. 30-31)

When Amanda reminds Laura "are you going to do what I asked you to do", it puzzles the readers because there is no reference to what Amanda expects Laura to do in any of the earlier action games. On the other hand, Laura relies on her background knowledge to understand the intended meaning of Amanda's utterance. The interlocutor's reference to 'butter' and 'what else' gives meaning to the context of the action game. Readers have to understand that the reference is made to a grocery shop because the noun 'butter' is a familiar word is associated with the grocery items. The phrase 'what else' conveys the abstract meaning related to other needed grocery items. Furthermore, the utterance of Amanda, 'tell them to charge it', means that the shopkeeper has to record the cost as an amount payable for purchasing 'butter.' Also, the reference to a non-verbal element in Laura's utterance, 'they make such faces', is clarified in Amanda's statement of "sticks and stones" and "Mr. Garfinkers face" to inform the readers that the reference is made to the possible reactions of grocery store owner.

In the dialogic exchange between Amanda and Laura, a cooperative attempt made by each of the characters, using their cognitive knowledge, leads to successful communication. This incoherent dialogic exchange introduced abruptly by the playwright progresses towards establishing coherence in the ongoing dialogue. The readers also cooperatively attempt to rely on the ongoing utterances of the interlocutors to comprehend the abrupt discourse introduced by the playwright to convey the poor economic conditions of the family.

Approaching the cooperative attempt, Weigand (2009) is of the opinion that understanding the dialogic language is beyond the literal meaning of a sentence. She points out that an effort to comprehend utterances implies that one is also trying to understand the function of the utterance in the context of dialogic interaction. Dealing with the open-system principle, she also added that the interlocutors give coherence to what is uttered on a cognitive basis by referring to personal assumptions that include preferences, habits, knowledge and memory. This argument supports the views of 
Givón (1993) which state that coherence in a text is an outcome of mental processes of discourse production and discourse comprehension but not an objective property of a text.

4.6 The Principle of Suggestion

In dealing with this principle of suggestion, researchers found out that Weigand is supporting the views of Dascal (1994), as the latter said that while concentrating on action games, with human beings as the centre, one can no longer restrict it only with rationality because individuals are also subjected to irrational tendencies. In the following dialogue, the actions and preferences of the character Tom suggest his irrational tendencies.

\section{Datum 8, Scene Four}

Amanda: But, Tom, you go to the movies entirely too much!

Tom: I like a lot of adventure. [...]

Amanda: Most young men find adventure in their career.

Tom: Then most young men are not employed in a warehouse. (P.35)

Tom seems quite irrational for his preference to 'go to the movies.' His egocentricity initiates him to think of his dreams and seek unrealistic adventures by going to the 'movies.' The utterance of Amanda signifies a suggestion to Tom that 'adventure' can be found even in his professional life. However, Tom does not talk about himself but rather he compares himself to many other young men of his age who work in better professions. Amanda's suggestions to make Tom realize the value of his job seems to be futile because the presumptions of Tom about the word 'adventure' does not go with the reasoning abilities of Amanda. The phrase 'not employed in a warehouse' depicts how young men like Tom, who are dissatisfied with their personal and professional life, suffers from unrealistic expectations and consequently 'justify' their current actions by comparing themselves to others.

The playwright shapes the discourse, deviating from the common belief that people usually go to movies for entertainment. The language of irrationality in Tom's argument supports his preferences and presumptions of the term 'adventure' rather than rationality.

4.7 The Rationality Principle

Weigand supports the views of Fodor (1987) that rationality of human beings are influenced by their beliefs and desires which in turn have an impact on their linguistic actions. Human beings orient themselves, in relation to the world with these mental states, to express a claim of truth or violation. There are instances where people control and stimulate their beliefs and desires which distinguish human beings from the animal physiology. Weigand also points out that human beings can initiate their thinking and question it innumerable number of times, justify and use the process of thinking in new contexts. The language of the discourse among the characters in The Glass Menagerie, furthermore, expresses their beliefs and desires in a seemingly rational attitude, making a claim of truth or violation. In the utterance below, for instance, the linguistic verbatim of Amanda indirectly refers to Tom's violation of moral values by addiction to alcohol.

Datum 9, Scene Four

Amanda: Promise, son, you'll-never be a drunkard! (P. 33)

Amanda rationalizes the claim for truth with a desire that Tom will "never be a drunkard" if he would "promise" to correct his irrational actions of taking alcohol. Tom's reactive utterance fulfills the claim requested by Amanda as he says:

Tom [turns to her grinning]: I will never be a drunkard, Mother. (P.33)

In the above utterance, Tom surrenders to the request of his mother's linguistic action. The response of the interlocutor signifies how an individual obliges to the principles of rationality, avoiding a verbal conflict with the speaker's (Amanda) claim and accepting the action of being a 'drunkard.'

In The Glass Menagerie, the playwright depicts the rational and irrational linguistic actions of different characters, to depict real-life situations and societal problems. As it is evident from the above dialogic action game between Amanda and Tom, the playwright reveals the mental states of beliefs and desires, which often rules the actions of human beings. Therefore, a part of the success of The Glass Menagerie lies in the playwright's linguistic ability to depict the mental states of the characters, using familiar communicative situations, and making connections to truth and violations.

4.8 The Conventionality Principle

Weigand points out that taking account of the conditions of the society; it is human beings who determine the evolution of language while they also have to follow the existing conventional ways of expressing themselves. In The Glass Menagerie, the usage of conventional words and phrases in a creative way suggests the playwright's ability to manipulate the dialogic language to convey the intended message.

Datum 10, Scene Five

Tom: One little warning. He doesn't know about Laura. I didn't let on that we had

dark ulterior motives. I just said, why don't you come and have dinner with us?

He said okay and that was the whole conversation. (P.49) 
In the above dialogue, the function of the phrase "ulterior motives" in conveying the intended meaning to the readers indicates the rule-governed pattern of language use. The playwright skillfully adhered to the conventions of language use because the word "ulterior" (adjective) often precedes motive (noun) to describe the nature of human actions which remain unknown to others. The playwright adds a contextually appropriate word "dark" before "ulterior motives" to create an impact on the discourse, signifying negativity in the attitude of the interlocutors. This communicative situation arises after Tom invites Jim for a dinner. The hidden motive of inviting Jim for a dinner is to give an opportunity for Laura to befriend and marry him. However, Tom makes sure that Amanda should not commit the mistake of revealing their "ulterior motives" to Jim. The response of Amanda also highlights the conventional lexis used to describe the qualities of a woman.

The above communicative situation correlates with Weigand's view that the conventional ways of language use determine how one can express rational thoughts and feelings. She further says that in the course of time, these conventional expressions become part of an individual's mental lexicon. The phrase "eloquent as an oyster" signals the playwright's conventional choice of lexis to exaggerate Amanda's observation of Tom's interaction with Jim.

\section{Datum 11, Scene Five}

Amanda: I bet it was! you're eloquent as an oyster. However, he'll know about Laura when he gets here. When he sees how lovely and sweet and pretty she is, he'll thank his lucky stars he was asked to dinner. (P.49)

Tennessee Williams' use of an old word like 'oyster' reminds us of Shakespeare's metaphorical use of the same word, i.e., "the world's mine oyster" in a different context, which he means to overcome stressful situations. A similar meaning of 'oyster' as "an extremely taciturn person" is found in Merriam-Webster English dictionary.

Tennessee Williams, in Amanda's talk, used familiar lexis like 'lovely', 'sweet', and 'pretty', to describe the female characteristics of Laura, emphasizing her physical features, thus making her personality appear more realistic. Williams' choice to elevate his context through such phrases like 'thank his lucky stars' makes the dialogic language appealing to the readers. These everyday expressions could probably belong to the active-vocabulary repertoire of ESL/EFL students and readers interested in literature, creating visual and realistic images of the characters. The language of the dialogic interaction between Tom and Amanda, though conventional in form, reflects the creativity of the playwright to communicate the psychological aspects that govern human behavior.

4.9 Principles of Emotions in Dialogue

Weigand is of the opinion that emotions, in dialogic interactions, cannot be isolated because they are dependent on how an individual sees and evaluates the world, and it also influences the sequence of other actions in a play. Referring to the unpredictability of the emotions, she states that it is not in one's head but in one's heart. She also added that linguists have to study the emotions in dialogue while a playwright is concerned with creating dialogues. Weigand also points out that the emotions influence the discourse of the dialogic action game, and it has not been systematically studied. In her view, analyzing emotions in a dialogue is a complex activity and an approach to study the language of dialogue is to identify independent dialogic units that communicate the emotions of the characters. In The Glass Menagerie, a sense of anger is apparent from the very beginning of the play. The following speech act is a revelation of Tom's displeasure and disgust towards Amanda's rude remarks on his dining mannerisms.

\section{Datum 12, Scene One}

Tom: I haven't enjoyed one bite of this dinner because of your constant directions on how to eat it. It's you that make me rush through meals with your hawklike attention to every bite I take. Sickening-spoils my appetite-all this discussion of-animals' secretion-salivary glands-mastication! (P.8)

The influence of emotion in Tom's utterance signifies the human nature of reacting to unpleasant discourse. Tom finds it unbearable to listen to Amanda's remarks like "animals' secretion", and "salivary glands" to associate his way of eating to that of animals. Tom accuses his mother of creating disorder in his state of mind by giving continuous directions on how to eat food. He depicted her complete attention to him like that of a hawk watching out its prey, thus giving hints about the dominating nature of Amanda. In this way the readers' attention is drawn to familiar terms of reference related to animal and human behavior, paving the way for quick comprehension. The playwright arouses the curiosity of the readers to the forthcoming situations in the play.

\section{Discussion of Findings}

In the 'Production Notes', Tennessee Williams points out that since The Glass Menagerie is a memory play, it "can be presented with unusual freedom of convention" (p. 1), which drew the attention of researchers to the dialogic principles of Weigand (2009). The findings of the current research examined the implied meanings and outcomes of different situations by the use of dialogic principles outlined by Weigand. The findings of the study support the ideas of Herman (1995) and Pavis (1998) that in order to make the dialogic discourse lively and dramatic in spatio-temporal settings, a playwright adheres to the style or genre of a spoken discourse.

5.1 Discourse of The Glass Menagerie: An Intermixture of Conventional and Unconventional Elements of Language Use

It is observed from the analsyis that the discourse of The Glass Menagerie is a combination of the conventional and creative use of language. In 'Production Notes' of The Glass Menagerie, Tennesse Williams states "when a play employs unconventional techniques, it is not, or certainly shouldn't be, trying to escape its responsibility of dealing with 
reality"(p. 1) coincides with the conventionality principle, wherein Weigand (2009) states that the dialogic language should take into account the existing conventional ways of expressing thoughts and feelings. An analysis of the discourse in The Glass Menagerie reveals that Williams' use of conventional expressions make the readers visualize and connect the incidents of play to real life situations. A reference made to Tennessee Williams 'unconventional techniques' has to be understood in the context of the dialogic discourse, wherein he intertwined natural feelings such as emotions, anger, pain, frustrations into the lexicons, thus shedding light on psychological aspects of human behavior.

5.2 Approaching The Glass Menagerie from Dialogic Principles of Weigand (2009)

The principles stated by Weigand facilitate a comprehensive understanding of The Glass Menagerie. Tennessee Williams' skill of intermixing verbal and cognitive elements into the dialogic language fulfills the features of a memory play. The ongoing linguistic actions among the characters often dwell around presuppositions, creating a sense of curiosity in the mind of the readers. When the characters are immersed in dialogic-conversation, their discourse seems to convey diverse views at the cognitive level but is quite interdependent at the structural level. The incomprehensibility of language cues like Laura's "shhh!" is an example of a minimal dialogic discourse through which the playwright controls the progression of the play. Also, there are many situations in the play where the utterances of the characters end abruptly, paving the way for the readers to predict and give meaning to the context. In this way, the playwright also involves the readers into the dialogic action game, triggering them to visualize the context and produce the language of their own. If these dialogic units are introduced in the language classrooms, students may require higher order cognitive skills to predict and make strings of meaningful sentences.

The discourse analysis of this play shows that there are different attitudes and variations among people in accepting or responding to different habits. The playwright depicts how differences in worldly views affects the tone of language to either accept, ridicule or correct the personal habits of other fellow beings. Readers, once encountered by the abrupt introduction of an action game, they have to use language tools like inference and supporting lexis to complete the meaning of the context. Furthermore, the language of rationality and irrationality through which the characters speak gives progression to the action game of the play. Studying the language of a text may enable readers to differentiate between the characters from the point of view of rationality and irrationality. On the other side, writers might select certain combinations of lexicons or phrases to create a negative or a positive influence on readers' intellect. In order to be independent from the influence of a writer, readers or researchers, studying the discourse of emotions, should not isolate or separate the accompanying part of a linguistic action game for making sense of the dialogic sequences.

5.3 Understanding the Play from the Context of Mutal Relationship between the Dialogic Purposes and Communicative Means

In The Glass Menagerie, the interaction among the characters in different real-life like communicative situations expressing their anger, frustration, disillusionment and love with appropriate dialogic language serves the dialogic purposes. The situations in which characters interact to confirm or reject social relationships seem to be so obligatory and realistic that the readers get immersed into the dialogic action games. These observations also support the views of Givón (1993) that coherence in a text is not an objective property of the text but an outcome of mental processess of discourse production and discourse comprehension of the readers. The interrelatedness of initiative and reactive speech acts increases readers' interest towards The Glass Menagerie.

It is observed that in most situations where Amanda and Tom interact, their language conveys impusliveness, agressiveness and remorse while at the same time Laura's role is to alleviate their agressiveness and impulsiveness. These observations on the dialogic language of Laura differ from the findings of Islamiah (2012) where Laura is considered to be violating the cooperative principle more dominantly when compared to other characters in The Glass Menagerie. During the progress of a sequence of dialogic action game, it is also observed that the playwright abrputly introduces certain communicative situations which seem to have no relationship to the earlier action games. However, the playwright communicates the reason for such a deviation through his characters, as in one instance Amanda says "I sent your sister so I could discuss something with you" (p. 33). This mutual relationship communicated through the discourse of the characters links the dialogic purposes to communicative means giving meaning to the sequence of events, and paving a way for comprehension in the minds of the readers. The phrase "unconventional technique", which Tennessee Williams referred to in 'Production Notes' reflects his creativity to communicate the purpose of introducing certain abrupt dialgoues through the discourse of the characters.

5.4 Approaching the Play from the Perspective of Dialogic Language

The dialogic language presented in The Glass Menagerie draws readers' attention to the creative use of lexis and phrases embedded in the discourse of the play. The playwright begins the opening scene of the play with a tone of spoken discourse by intentionally disregarding the use of punctuations to create a verbal and visual effect in the readers mind. In the opening lines of the play, furthermore, the playwright uses an informal tone to establish a personal contact with the readers by introducing characters and showing his relationship to them using personal pronouns like 'I', 'my mother, 'my sister' and 'our father'. These features of dialogic language support the views of Pavis (1998) that the playwright reproduces the style or genre of spoken discourse to create a dramatic effect in the minds of the readers. In The Glass Menagerie, Tennessee Williams has included very short as well as extended dialogues among the characters. He seems to have chosen these short dialogues with a purpose of brevity and suitability to a given situation. Such a dialogic unit which is constituted either by a word or a phrase has an impact on the rapidity of linguistic and nonlinguistic actions among the characters. These incomplete intended sentences demands the readers to perceive the playwright's unspoken words, phrases, and messages. Further, the intention of the playwright to manipulate brevity in his text not only covers language aspects but also embodies emotions to use their cognitive skills during the reading process. Another discourse feature that characterizes this play is merging of past, present and future events in a dialogic 
action game. When the characters meet and exchange dialogues, they tend to refer to the past events as we find in an instance where Amanda refers to "one Sunday afternoon in Blue Mountain" (p. 9) giving a suddenly shift from the present context to her past memories.

\section{Conclusion}

This paper has presented a discourse analysis of The Glass Menagerie. In doing so, the researchers relied on the nine dialogic principles stated by Weigand (2009). Researchers found that the application of these principles clarified the conventional and unconventional techniques of language use in The Glass Menagerie. Applying the principles of Weigand, the researchers could deduce abstract linguistic concepts embedded in the dialogic language of the play. The intensity of feelings and emotions in the linguistic actions of the characters are analyzed in order to understand the lexis and phrases. This process consequently enhanced the understanding of intended hidden meanings of the text, and also gives insights to the abstract issues and feelings which are conveyed to the readers using conversational tone. This study will help readers to explore meaning behind clauses and phrases intertwined in each of the dialogue.

\section{References}

Barnard, D. B. (2007). The Symbolism of Tennessee Williams' The Glass Menagerie an Inductive Approach (Unpublished master's thesis). Louisiana State University and Agricultural and Mechanical College.

Chowdury, Abhishek. (2014). Memory, Desire and the American Dream in Tennessee Williams' The Glass Menagerie. European Academic Research, II (2), 1891-1902.

Daneš, František. (1997). Observations about the Sound Shape of Spontaneous Discourses. In Edda Weigand (eds.), Dialogue Analysis: Units, Relations, and Strategies Beyond the Sentence. Contributions in honour of Sorin Stati's 65th birthday, (pp. 65-74). Tübingen: Niemeyer.

Dascal, Marcelo. (1994). Speech Act Theory and Gricean Pragmatics: Some Differences of Detail that Make a Difference. In Savas L. Tsohatzidis (eds.), Foundations of Speech Act Theory: Philosophical and Linguistic Perspectives, (pp.323-334). London/New York: Routledge.

Fernkorn, Maria. (1999). Character Constellation and Characterization in Tennessee Williams "The Glass Menagerie" (First ed.). Germany: GRIN Verlag.

Fodor, Jerry Alan. (1987). Psychosemantics: The Problem of Meaning in the Philosophy of Mind. Cambridge, Mass. London: MIT Press.

Friedrich, Toni. (2010). The "Soft People" of Laura and Tom Wingfield in 'The Glass Menagerie' and Blanche DuBois in 'A Streetcar named Desire' (1st ed.). Germany: GRIN Verlag.

Givón, Talmy. (1993). Coherence in Text and in Mind. Pragmatics \& Cognition 1: 171-227.

Gräfe, Annett. (2007). Portrait of a Mother in Tennessee Williams' Memory Play 'The Glass Menagerie'. Germany: GRIN Verlag.

Hama, B. S. (2016).Accessing Text through Context: Padding Conversational Gaps in The Glass Menagerie and a Raisin in the Sun. Journal of Literature, Languages and Linguistics, 18, 10-20. Retrieved March 26, 2016, from http://iiste.org/Journals/index.php/JLLL/article/view/28308/29051

Hart, H. C. (1904). The Works of Shakespeare: The Merry Wives of Windsor. Retrieved February 3, 2016, from http://warburg.sas.ac.uk/pdf/emh81b2457073.pdf

Herman, V. (1995). Dramatic Discourse: Dialogue as Interaction in Plays. London and New York: Routledge. Hoffmannová, A. (n.d.). Exceptionality Versus Normativity In The Glass Menagerie. Retrieved March 26, 2016, from https://www.ff.umb.sk/app/cmsFile.php?disposition=a\&ID=19346

Islamiah, A. (2012). The Flouting of Cooperative Principle in Drama “The Glass Menagerie” (A Pragmatic Analysis) (Unpublished Bachelor thesis). Hasanuddin University.

King, T. L. (1973). Irony and Distance in "The Glass Menagerie" Educational Theatre Journal, 25(2), $207-214$. Retrieved from http://ccurley.pbworks.com/w/file/fetch/89377232/Irony and Distance in The Glass Menagerie.pdf Lunden, J. (2013 a, September 26). An American Masterpiece, And A 'Menagerie' Of Stars. Retrieved February 05, 2016, from http://kcur.org/post/american-masterpiece-and-menagerie-stars

Lunden, J. (2013 b, October 22). Broadway Revives Tennessee Williams' 'Glass Menagerie' Retrieved November 11, 2015, from http://www.voanews.com/content/broadway-revives-tennessee-williams-glass-menagerie/1774823.html Maruejouls-Koch Sophie (2012) Absorbing Images: Tennessee Williams's "Plastic Theatre" and European Painting. The Tennessee Williams Annual Review 13, 12-31.

Pavis, P. (1998). Dictionary of the Theatre: Terms, Concepts and Analysis. University of Toronto Press.

Syed, J.W (n.d.). Expressionism in the Twentieth Century Literature. Retrieved September 6, 2015, from http://www.allamaiqbal.com/publications/journals/review/apr70/3.htm

Tabasum, I. A. (2013). Deconstructing Pessimistic Discourse in the Plays of Tennessee Williams. PhD Thesis, Lahore University of Management Science, Lahore. Retrieved March 26, 2016, from http://prr.hec.gov.pk/Thesis/2063S.pdf

Verdonk, P. (2013). The Stylistics of Poetry: Context, Cognition, Discourse, History (2013 ed.). New York: Bloomsbury.

Weigand, E. (2009). Language as Dialogue from Rules to Principles of Probability (S. Feller, Ed.). Amsterdam: John Benjamins Pub.

Williams, T. (2002). The Glass Menagerie (L. McPherson, Ed.). Beirut: Librairie Du Liban Paperbacks. 